\title{
Does asthma control as assessed by the asthma control test reflect airway inflammation?
}

\section{II controllo dell'asma valutato con l'“'asthma control test" rispecchia l'infiammazione delle vie aeree?}

\author{
Mine Bora ${ }^{1}$, Aylin Ozgen Alpaydin ${ }^{1}$, Arzu Yorgancioglu' ${ }^{1}$, Gizem Akkas ${ }^{2}$, Aydın Isisag², \\ Aysın Sakar Coskun ${ }^{1}$, Pınar Celik ${ }^{1}$ \\ ${ }^{1}$ Celal Bayar University Medical Faculty, Department of Pulmonary Diseases, Manisa, Turkey \\ ${ }^{2}$ Celal Bayar University Medical Faculty, Department of Pathology, Manisa, Turkey
}

\section{ABSTRACT}

Background and aims: The treatment of asthmatic patients is particularly focused on the control of symptoms as well as functional and inflammatory parameters. In our study, we investigated the relationship between the asthma control test (ACT) which evaluates symptoms and airway inflammation and functional parameters.

Materials and methods: Stable asthmatic patients admitted to our pulmonary outpatient clinic were enrolled in the study consecutively and underwent the ACT, pulmonary function tests and methacholine bronchial provocation test (MBPT). Additionally, fractional exhaled nitric oxide level (FeNO) and induced sputum cell distribution were assessed. All these parameters were re-evaluated at the third month after adjusting medications of the patients according to baseline ACT scores.

Results: Of the 101 patients screened, we analyzed 83 who proceeded to the follow up visit. At the baseline visit, 8 were totally controlled, 36 partially controlled and 39 uncontrolled according to ACT. At the follow up visit, 10 were totally controlled, 39 partially controlled and 34 uncontrolled. Comparison of the two visits in terms of all parameters revealed significant reductions only in the percentages of patients with MBPT positivity $(p=0.029)$ and FeNO levels > $20 \mathrm{ppb}(\mathrm{p}=0.025)$ at follow up. The percentages of patients with $\mathrm{FeNO}>20 \mathrm{ppb}, \mathrm{MBPT}$ positivity, induced sputum eosinophilia or induced sputum neutrophilia did not show significant differences between totally controlled, partially controlled and uncontrolled groups at both baseline and fol- low up visits.

Conclusion: Although the ACT scores did not show significant correlations with the airway inflammation parameters tested in this study, a marked reduction in the percentage of patients with MBPT positivity and FeNO $>20 \mathrm{ppb}$ at follow up may suggest the importance of the control concept in the management of asthma.

Keywords: Airway eosinophilia, asthma control test, exhaled nitric oxide, methacholine bronchial provocation test.

\section{RIASSUNTO}

Razionale e scopo: Il trattamento dei pazienti asmatici si concentra in modo particolare sul controllo dei sintomi, parallelamente ai sui parametri funzionali e infiammatori. Nel nostro studio abbiamo indagato i rapporti fra l'"asthma control test" (ACT), che valuta la sintomatologia, con l'infiammazione delle vie aeree e i parametri funzionali.

Materiali e metodi: Sono stati arruolati pazienti asmatici consecutivi in fase stabile afferenti al nostro ambulatorio di pneumologia, e sottoposti a compilazione dell'ACT, test di funzionalità respiratoria, test di provocazione bronchiale con metacolina (MBPT), misurazione della frazione espiratoria di ossido nitrico (FeNO) e citologia dell'espettorato indotto. Tutti questi parametri sono stati rivalutati a tre mesi dopo aggiustamento per il trattamento farmacologico sulla base dei punteggi ACT di base.

Risultati: Su 101 pazienti sottoposti a screening, ne sono stati valutati 83 che si sono ripresentati alla visita di follow up. Alla

\section{$\fallingdotseq$ Aylin Ozgen Alpaydin}

Celal Bayar University Medical Faculty, Department of Pulmonary Diseases

45010 Manisa, Turkey

email: aylin.ozgen@yahoo.com

Data di arrivo del testo: 20/02/2011 - Accettato dopo revisione: 06/05/2011

Multidisciplinary Respiratory Medicine 2011; 6(5): 291-298 
prima visita 8 pazienti erano totalmente controllati, 36 parzialmente controllati e 39 non controllati in base all'l'ACT. Nella visita di follow up, 10 pazienti erano completamente controllati, 39 parzialmente controllati e 34 non controllati. La comparazione fra le due visite ha evidenziato, fra tutti i parametri, una riduzione significativa solo nella percentuale di pazienti con positività a MBPT $(p=0,029)$ e livelli di FeNO > $20 \mathrm{ppb}(\mathrm{p}=0,025)$ al follow up. La percentuale di pazienti con FeNO > $20 \mathrm{ppb}$, positività al MBPT, eosinofilia neutrofilia nell'espettorato indotto non hanno mostrato significative differenze tra i gruppi di pazienti ben controllati, parzialmente controllati e non controllati sia alla prima visita che al follow up.

Conclusioni: Anche se i punteggi dell'ACT non hanno mostrato correlazioni significative con i parametri di infiammazione delle vie aeree valutati in questo studio, la marcata riduzione della percentuale di pazienti con positività al MBPT e FeNO > 20 ppb alla visita di follow up può implicare l'importanza del concetto di controllo nella gestione dell'asma.

Parole chiave: "Asthma control test", eosinofilia delle vie aeree, ossido nitrico espirato, test di stimolazione bronchiale con metacolina.

\section{INTRODUCTION}

Asthma is a chronic disease characterized by inflammation of the airways [1]. It has been reported that the inflammatory process is strongly correlated to airway hypersensitivity and asthma symptoms. Monitoring the severity of the disease and treatment response by evaluating airway inflammation may enable a better control of the disease [2].

Current guidelines for the diagnosis and treatment of asthma have particularly focused on managing asthma according to the control concept rather than to disease severity as such [3]. Asthma control should ideally be evaluated in terms of pulmonary function, inflammatory parameters and quality of life. It is difficult, expensive and time-consuming to evaluate all these parameters together in the routine clinical practice. Thus, simple and rapid methods are needed to evaluate the asthma control. Several questionnaires providing numeric values have been developed to differentiate asthma control levels, mainly evaluating the clinical control of the patients. Among the questionnaires approved by GINA 2006, the recommended tests are: the Asthma Control Test (ACT), Asthma Control Questionnaire (ACQ), and Asthma Therapy Assessment Questionnaire (ATAQ). ACT which has been adapted to the Turkish population is easy to perform [4-7].

The importance of chronic airway inflammation in asthma has been well documented; clinical symptoms and disease severity have been shown to be related; besides, marked clinical improvement has been reported via the suppression of inflammation [8]. In the follow up of inflammation, the evaluation of sputum eosinophil rates and fractional exhaled nitric oxide (FeNO) levels have also been recommended along with the monitoring of bronchial hyperreactivity [9].

Increased NO levels have been observed in the airways and expired air of asthmatic patients. This in- crease is attributed to the activity of inducible NO synthase (iNOS) in the airway epithelial cells and macrophages [10]. A significant clinical relationship has been demonstrated between FeNO levels and eosinophilic inflammation [11]; however, a considerable amount of false negative and positive findings have been observed [12]. Although FeNO measurement can provide information about the disease activity characterized by eosinophilic airway inflammation, it is not useful in more severe disease forms especially in the presence of neutrophilic inflammation [13]. FeNO levels of $<35$ ppb are accepted as normal values for healthy adults when measured by standard methods in different populations; however the recommended value, after exclusion of extreme values and atopics, is $20 \mathrm{ppb}[14,15]$. It is not possible to give standard normal reference values for asthmatic patients; thus, individual serial measurements may provide "stable period" values for asthmatics [13]. Bronchial hyperreactivity (BHR) is one of the most important characteristics of asthma. BHR measurements can demonstrate variable airflow limitation objectively. BHR presence has also been shown to be a risk factor for impaired pulmonary function in asthmatic patients [16]. Basal methacholine response of asthmatic patients can predict the spirometric therapeutic response to inhaled corticosteroids [17]. Individual therapies considering BHR may shorten uncontrolled periods in asthmatic patients [18]. Thus, BHR has been suggested as a valuable indirect marker for asthma control.

Induced sputum examination has been used as a non-invasive rapid diagnostic method for determining airway inflammation [3]. Induced sputum has been reported to be an objective tool for monitoring treatment response as well as for assessing asthma attacks and disease severity in asthmatics [13]. Eosinophilia in induced sputum examination is particularly useful for predicting the benefit of other inflammatory drugs for symptomatic asthmatic patients, including those on inhaled steroid therapy [19].

In this study, we aimed to investigate the relationship between ACT - a simple questionnaire for the evaluation of asthma control - and pulmonary function, methacholine bronchial provocation test (MBPT) results, FeNO levels and induced sputum eosinophilia. We also looked for alterations in these parameters after adjustment of the treatment regimen according to ACT.

\section{MATERIALS AND METHODS}

For the present study, 101 consecutive patients aged between 18 and 65 years who were admitted to our pulmonary outpatient clinic between 2008 and 2009 with a diagnosis of mild or moderate asthma according to GINA 2006 criteria were screened. All patients read and signed the informed consent after being informed about the study protocol.

According to the study protocol, a baseline visit was carried out in all patients. At this visit, the patients' 
treatments were adjusted according to their ACT scores and patients were asked to come 3 months later for the follow up visit. At each visit, patients were questioned about their symptoms of asthma on the first study day and then they underwent ACT, measurement of FeNO, pulmonary function tests and MBPT. Induced sputum investigation was performed 24 hours later.

\section{Asthma control test (ACT)}

The ACT is a patient-based 5-item questionnaire that investigates the disease control [5]. Patients are questioned about their perception of asthma control in the previous 4 weeks. For each question there are five possible answers, with the score ranging from 1 to 5: the total minimum and maximum scores are 5 (poorest asthma control) and 25 (optimal asthma control), respectively. Depending on the ACT scores, we classified the patients into three groups as follows: totally controlled (ACT $=25)$, partially controlled (ACT = 20-24) and uncontrolled (ACT $\leq$ 19). Thereafter, the totally controlled and partially controlled patients were re-grouped as controlled group (ACT > 19) whereas the uncontrolled patients remained in the uncontrolled group.

\section{Pulmonary function test}

The pulmonary function test was performed in sitting position with nose closed. The test was repeated three times using a spirometer (Jaeger Master Screen Pneumo Spirolab II ${ }^{\circledR}$ ). Forced expiratory volume in one second $\left(\mathrm{FEV}_{1}\right)$, forced vital capacity (FVC), and the $\mathrm{FEV}_{1} / \mathrm{FVC}$ ratio were measured according to the ATS criteria and the best values were recorded [20].

\section{Methacholine bronchial provocation test}

Patients underwent a methacholine provocation test according to the 2-min breathing protocol as described in ATS guideline. The patients inhaled methacholine at the doses of 0.0625, 0.125, 0.250, $0.500,1,4,8$ and $16 \mathrm{mg} / \mathrm{mL}$ after three repetitive $\mathrm{FEV}_{1}$ measurements. Thereafter, the pulmonary function test was repeated. The dose which caused a $20 \%$ or more decrease in baseline $\mathrm{FEV}_{1}$ value was accepted as provocative dose $\left(\mathrm{PD}_{20}\right)$ [21]. A $\mathrm{PD}_{20}$ value of $<8 \mathrm{mg} / \mathrm{mL}$ was accepted as an indicator of positive BHR.

\section{Measurement of exhaled NO (FeNO) level}

Before the spirometric measurements, FeNO level was assessed during one exhalation (flow rate 0.05 liters/second) using a nitric oxide analyzer (NIOX MINO Airway Inflammation Monitor; Aerocrine AB; Solna, Sweden). The unit was expressed as parts per billion (ppb). The measurement was performed according to American Thoracic Society/European Respiratory Society (ATS/ERS) guidelines. The patients inhaled 'NO deficient air' for 2-3 seconds in sitting position via a mouthpiece up to the limit of total lung capacity. Then they were asked to exhale under a flow rate of 0.06 liters/second against a resistance of $5 \mathrm{~cm} \mathrm{H} \mathrm{H}_{2} \mathrm{O}$ created by the mouthpiece.
Following the inspiration of free air, the patient fully exhaled into the apparatus through the mouthpiece. The nose was not closed, so as to prevent contamination with nasal air during exhalation. Exhalation period was set over 6 seconds to reach the plateau concentration [22]. FeNO threshold was accepted as $20 \mathrm{ppb}$.

\section{Induction of sputum}

After medication with a short-acting $\beta_{2}$ agonist, sputum was induced by inhalation of $3 \%$ hypertonic saline by a nebulizer (Pari Master, Pari Respiratory Equipment Inc. Richmond, VA, USA) with an output of $0.5 \mathrm{ml} / \mathrm{min}$ saline for a maximum period of 20 minutes via a mouthpiece. The patients were encouraged to cough and expectorate sputum in a sterile petri dish 10 minutes after the onset of nebulization and every 5 minutes. Three flow-volume curves were obtained before and after each inhalation for patients with a $\mathrm{FEV}_{1}$ value $<80 \%$. The sputum induction was terminated when a $>15 \% \mathrm{FEV}_{1}$ decrease was observed in comparison to baseline value or when a symptom occurred. The procedure was terminated before 20 minutes if the nebulization was sufficient and sputum was appropriate $[23,24]$.

\section{Processing of sputum}

All samples were processed within 2 hours according to a method modified from Popov et al. [23,24]. All viscid or denser portions from the expectorated sample were selected using the "plug selection" method, placed in an eppendorf tube and weighed. Dithiothreitol (DTT; Sigma) was freshly prepared with a dilution of 1:10 with distilled water and added at a volume equal to two times the weight of the sample. Then, the sample was mixed mechanically by 20 times back and forth pipetting. Afterwards, the sample was placed in a shaking water bath at $25^{\circ} \mathrm{C}$ for $15 \mathrm{~min}$ to ensure complete homogenization. Further dilution was performed with phosphate buffered saline (PBS) in a volume equal to the sputum plus DTT and the reaction of DTT was terminated. Then the suspension was filtered through nylon gauze (52 micrometer), the supernatant was aspirated and the cell pellets were resuspended with Roswell Park Memorial Institute (RPMI) media to achieve a concentration of 10/L. Finally, one drop was put in each cytocentrifuge cube and cytocentrifuged at $600 \mathrm{rpm}$ for $10 \mathrm{~min}$ utes. The cytospins were stained with Giemsa. Differential cell counts were measured by scanning slides starting at the top left corner in an undulating manner from top to bottom using high power (x100) magnification. Two hundred non-squamous cells were counted and the results were expressed as a percentage of total non-squamous cell counts. The threshold for eosinophilia in induced sputum was set as 3\%.

\section{Medication adjustment}

Measures were collected in this cohort at the baseline and 3-month follow up visit. Based on ACT control status, treatment was adjusted where neces- 
sary at baseline by stepping down (reducing the number or dose of medication used) therapy in controlled patients (ACT $=25)$, or stepping up (increasing the number or dose of medication used) therapy for uncontrolled (ACT < 20) and partially controlled (ACT between 20-24) patients. In some controlled $(\mathrm{ACT}=25)$ and partially controlled patients (ACT between 20-24) no therapy adjustment was made.

\section{Statistical analysis}

We used a "modified" intent-to-treat analysis and all participants who completed follow up were analyzed. Student's paired t test was used to compare ACT score, $\mathrm{FEV}_{1}$ and $\mathrm{FEV}_{1} / \mathrm{FVC}$ ratios determined at baseline and follow up visits. The Wilcoxon signed rank test was used for the comparison of FeNO levels and sputum neutrophil counts between baseline and follow up. The McNemar test was used to compare the MBPT positivity and sputum eosinophilia between baseline and follow up. The ACT score categories of the patients at baseline and follow up were compared using the McNemar-Bowker test. Parameters between patients grouped depending on their ACT scores were compared using the Chisquared test. The correlations between ACT scores and pulmonary function tests were assessed by the Pearson test. Correlations between ACT scores and eosinophil and neutrophil counts in induced sputum were assessed by the Spearman test. Values of $p<0.05$ were regarded as statistically significant. The data were analyzed using SPSS version 14 software package.

\section{RESULTS}

\section{Patient characteristics}

Among the 101 screened patients, 18 had to be excluded due to asthma attacks $(n=2)$, pregnancy ( $=2)$ or because lost to follow up $(n=14)$ at the $3^{\text {rd }}$ month follow up visit. The participants excluded were not found statistically significant different from the analyzed patients in terms of age $(p=0.505)$, sex $(p=0.223), F_{1} V_{1} \%(p=0.520)$, atopy $(p=$ $0.718)$, smoking history ( $p=0.406)$ or total ACT score $(p=0.366)$; so a "modified" intent-to-treat analysis was performed and the data of 83 patients were analyzed.

The mean age of the 83 patients analyzed (13 males and 70 females) was $42.3 \pm 11.4$ years. The median of disease duration was 2 years (range 0.5-22). Twenty-three percent of the patients were current smokers, $68 \%$ were non-smokers and $9 \%$ were exsmokers. Nine patients had diabetes mellitus, 16 had cardiovascular disease, 7 had defined prominent atopy and 8 had two or more asthma attacks a year. None of the patients had other obstructive diseases and all were on medication with inhaled steroids or inhaled steroids and bronchodilators which their disease state necessitated.

Asthma control level, pulmonary function tests and MBPT

At the baseline visit, 8 patients were totally con- trolled, 36 were partially controlled and 39 were uncontrolled. The mean ACT score was $18.98 \pm$ 4.59. At the follow up visit, 10 patients were totally controlled, 39 partially controlled and 34 were uncontrolled. Mean ACT score was $19.65 \pm 4.11$. Thus, no significant change was observed between the two visits in terms of ACT score $(p=0.164)$ (Table I).

At the baseline visit, the mean $\mathrm{FEV}_{1}$ was $2.59 \pm 0.62$ liters $(93.9 \pm 13.7 \%)$. Similarly to ACT scores, no significant change was observed between the two visits in terms of pulmonary function tests $\left(\mathrm{FEV}_{1}\right.$, $\mathrm{FEV}_{1} / \mathrm{FVC}$ ) (Table I).

Analysis of the relationship between ACT scores and pulmonary function parameters at baseline visit showed no significant correlation between ACT and $\mathrm{FEV}_{1}(\mathrm{~L})(\mathrm{r}=-0.003, \mathrm{p}=0.981)$.

At the baseline visit, $59 \%$ of the patients had a positive MBPT. MBPT positivity was observed in $62 \%$ of the controlled patients. At baseline, there was no significant difference among totally controlled, partially controlled and uncontrolled patients in terms of MBPT positivity $(p=0.852)$ (Table II). At the follow up visit, MBPT positivity was observed in $45 \%$ of all patients, and in 30\% of the controlled patients. Similarly, there was no significant difference among totally controlled, partially controlled and uncontrolled patients in terms of MBPT positivity at the follow up visit $(p=0.250)$ (Table II). However, the percentage of patients with MBPT positivity showed a statistically significant reduction in the follow up visit $(p=0.029)$ (Table I).

\section{Evaluation of FeNO}

At baseline, the median FeNO level of patients was $15 \mathrm{ppb}$ (Table I). Thirty-eight percent of the totally controlled patients had FeNO levels $>20 \mathrm{ppb}$. The proportion of patients with FeNO levels $>20$ ppb did not show significant differences among the three ACT groups $(p=0.054)$, being highest in the partially controlled group (Table II). The mean ACT scores at baseline did not show any correlation with FeNO levels $(r=0.111, p=0.318)$.

The proportions of patients with FeNO levels $>20$ ppb were $21 \%, 45 \%$ and $38 \%$ in current smokers, non-smokers and ex-smokers, respectively $(\mathrm{p}=$ 0.189 ).

At the follow up visit the median of FeNO was 14 ppb (Table I). Although statistically insignificant, the frequency of the uncontrolled patients with FeNO levels $>20 \mathrm{ppb}$ was found to be higher than that of the others ( $p=0.381$ ) (Table II). As shown in Table I, the comparison of the median of FeNO levels obtained at the baseline and follow up visits demonstrated a statistically significant change $(p=0.025)$.

\section{Airway inflammation}

At baseline, 62 patients had sputum analysis available; of these 47 had a sputum sample available at the third month. Twenty-three percent of these patients had $>3 \%$ eosinophilia and none of the totally controlled patients had sputum eosinophilia. The median of neutrophil percentage was $26 \%$ in totally 
TABLE I: ACT SCORES, PULMONARY FUNCTION AND INFLAMMATORY PARAMETERS OF THE STUDY PATIENTS AT THE BASELINE AND FOLLOW UP VISITS

controlled patients. There was no significant difference among totally controlled, partially controlled and uncontrolled patients in terms of induced sputum eosinophilia and induced sputum neutrophil counts $(p=0.398$ and $p=0.490$, respectively) (Table III). Similarly, there was no statistically significant correlation between baseline ACT scores and induced sputum eosinophilia or neutrophil counts $(r=-0.084, p=0.573$ and $r=-0.123, p=0.411$, respectively).

At the follow up visit, 30 patients who gave sputum were analyzed. Among these, $30 \%$ had a sputum eosinophil percentage of $>3 \%$. The median of sputum neutrophil percentage was $42 \%$ in totally controlled patients. There was no significant difference among totally controlled, partially controlled and uncontrolled patients in terms of induced sputum eosinophilia and induced sputum neutrophil counts ( $p=0.644$ and $p=0.810$, respectively) (Table III). We could not find any statistically significant change in induced sputum eosinophilia and neutrophil percents at baseline and follow up visits ( $p=$
0.791, $\mathrm{p}=0.241$ respectively) (Table I).

\section{DISCUSSION}

Asthma is a chronic inflammatory disease of the lower airways that is characterized by bronchial hyperreactivity and diffuse reversible airway ob-

be controlled by effective treatment. Guidelines on asthma control have been based particularly on clinical and functional evaluations. Currently, monitoring airway inflammation has become one of the most important targets of asthma control. ACT has been developed for the clinical evaluation of disease control, while measurement of FeNO and eosinophil rates in induced sputum are recommended for the evaluation of inflammation $[2,3]$. In this study, we investigated the relationship between ACT and pulmonary functions, bronchial reactivity, FeNO level and eosinophilia in induced sputum and the alterations in these parameters after adjustment of the treatment regimen according to ACT.

TABLE II: MBPT POSITIVITY AND FENO 20 PPB RATES OF THE STUDY PATIENTS GROUPED ACCORDING TO ACT SCORES AT BASELINE AND FOLLOW UP

\begin{tabular}{|c|c|c|c|c|c|c|c|}
\hline & \multicolumn{2}{|c|}{ Totally controlled } & \multicolumn{2}{|c|}{ Partially controlled } & \multicolumn{2}{|c|}{ Uncontrolled } & \multirow[b]{2}{*}{$\mathrm{p}$} \\
\hline & $\mathrm{n}$ & $\%$ & $\mathrm{n}$ & $\%$ & $\mathrm{n}$ & $\%$ & \\
\hline Baseline & \multicolumn{2}{|c|}{$(n=8)$} & \multicolumn{2}{|c|}{$(n=36)$} & \multicolumn{2}{|c|}{$(n=39)$} & \\
\hline MBPT positivity & 5 & $62 \%$ & 20 & $56 \%$ & 24 & $62 \%$ & 0.852 \\
\hline FeNO > 20 ppb & 3 & $38 \%$ & 19 & $53 \%$ & 10 & $25 \%$ & 0.054 \\
\hline $3^{\text {rd }}$ month follow up & \multicolumn{2}{|c|}{$(n=10)$} & \multicolumn{2}{|c|}{$(n=39)$} & \multicolumn{2}{|c|}{$(n=34)$} & \\
\hline MBPT positivity & 3 & $30 \%$ & 21 & $54 \%$ & 13 & $38 \%$ & 0.250 \\
\hline FeNO>20 ppb & 2 & $20 \%$ & 10 & $26 \%$ & 13 & $38 \%$ & 0.381 \\
\hline
\end{tabular}

Definition of abbreviations: FeNO, exhaled nitric oxide; MBPT, methacholine bronchial provocation test. 


\begin{tabular}{|c|c|c|c|c|}
\hline & Totally controlled & Partially controlled & Uncontrolled & P \\
\hline \multicolumn{5}{|l|}{ Baseline } \\
\hline $\begin{array}{l}\text { Induced sputum eosinophil > 3\%, } \\
\mathrm{n} / \mathrm{N}(\%)\end{array}$ & $0 / 5(0)$ & $5 / 21(23)$ & $6 / 21(29)$ & 0.398 \\
\hline $\begin{array}{l}\text { Induced sputum neutrophil (\%) } \\
\text { median ( } 1^{\text {st }} \text { and } 3^{\text {rd }} \text { quartiles) }\end{array}$ & $26(10-44)$ & $22(9-45)$ & $33(15-57)$ & 0.490 \\
\hline \multicolumn{5}{|l|}{$3^{\text {rd }}$ month follow up } \\
\hline $\begin{array}{l}\text { Induced sputum eosinophil } \\
>3 \% \mathrm{n} / \mathrm{N}(\%)\end{array}$ & $2 / 4(50)$ & $4 / 15(27)$ & $3 / 11(27)$ & 0.644 \\
\hline $\begin{array}{l}\text { Induced sputum neutrophil (\%) } \\
\text { median ( } 1^{\text {st }} \text { and } 3^{\text {rd }} \text { quartiles) }\end{array}$ & $42(29-53)$ & $28(18-56)$ & $46(18-64)$ & 0.810 \\
\hline
\end{tabular}

We found that controlled patients had less bronchial reactivity and lower FeNO levels with respect to controls although they were not significantly associated. We also demonstrated significant improvements in bronchial reactivity and FeNO levels at the follow up visit.

According to data from the AIRE and INSPIRE studies, the asthma control level determined with questionnaires is not concordant with patients' own perception $[25,26]$. The AIRE study showed that only $45 \%$ of the asthmatic patients in Turkey have their asthma under control [27]. Similarly, in our study, according to ACT scores $53 \%$ of the patients had their asthma under control (ACT score $>19$ ) at the baseline visit, while at the follow up visit $59 \%$ had asthma under control after therapy adjustment. Bateman evaluated 3,421 uncontrolled asthma patients and reported that in the poorly controlled group at baseline no control was achieved in spite of high doses of inhaled corticosteroid therapy. This finding indicates that unless inflammation is not completely suppressed, control may not be achieved in some asthmatic patients [4]. In our study, there was no statistically significant difference between the ACT scores observed at the baseline and follow up visits. However, the percentage of patients controlled showed an increase from $53 \%$ to $59 \%$. These rates which are lower than expected may be due to patients' weak perception of their disease state or continuation of the inflammation at the control visit (after 3 months). Indeed, the presence of eosinophilia in induced sputum of patients at the follow up visit (30\%) (although only half of the patients gave sputum appropriate for analysis) indicates that inflammation is not totally under control.

The relationship between signs and symptoms in asthma patients is generally weak. There are studies demonstrating no association between the pulmonary function tests and symptoms of the patients regardless of the perception level [28]. On the contrary, other studies have reported a weak relationship between ACT and $\mathrm{FEV}_{1}$ in patients with asthma $[5,29]$. In our study, no statistical significance was observed between ACT scores and $\mathrm{FEV}_{1}$ at either baseline or follow up visits. The exact influence of airway hypersensitivity measurement on the asthma management is controversial [1]. A study evaluating bronchial hyperreactivity in asthmatic patients has shown that $86 \%$ of totally controlled patients had MBPT positivity and suggested that airway inflammation and bronchial hypersensitivity continues even in a totally controlled state [30]. There are studies which have shown poor asthma control in patients with MBPT positivity $[31,32]$. In our study, the proportion of patients with positive MBPT showed a statistically significant decrease within three months of follow up and treatment. When the association between asthma control level and MBPT positivity was analyzed, MBPT positivity was observed in $62 \%, 56 \%$ and $62 \%$ of the totally controlled, partially controlled and uncontrolled patients at the baseline visit. At the follow up visit, these figures decreased to $30 \%, 54 \%$ and $38 \%$, respectively.

In asthmatic patients iNOS is activated via cytokines from inflammatory cells and a high amount of NO is synthesized [10]. It has been documented that in asthmatic patients on steroid therapy the amount of $\mathrm{NO}$ given in exhaled air is decreased to levels of healthy people $[33,34]$. In a study investigating the impact of FeNO measurement in expired air on asthma control, it was suggested that anti-inflammatory therapies adjusted according to ACT scores might not be sufficient, although a relationship was observed between ACT scores and FeNO [32]. Another study which found a relationship between FeNO level and airway inflammation reported that FeNO might not predict the severity of asthma [35]. In our study, evaluation of patients with FeNO > 20 ppb among totally controlled, partially controlled and uncontrolled groups demonstrated that the percentage of patients with FeNO $>20$ ppb was highest in the partially controlled group $(p=0.054)$. However, it has been reported that asthmatic patients may have FeNO levels higher than healthy controls even in stable state. Thus, the reference values for asthmatic patients may not be completely accurate [36]. Therefore, a comparison based on patients' individual values is recommended. In our study, a small but significant reduction was observed in FeNO values at the follow up visit after therapy adjustment ( $p=0.025)$.

Smoking is known to be associated with increased 
oxidative stress and decreased $\mathrm{NO}$ production in the airways. In a study measuring FeNO 15 minutes after smoking, FeNO levels were found to be higher in smoker asthmatic steroid naive patients than healthy smokers. In both healthy and asthmatic smokers, FeNO levels were lower than in those who did not smoke. Smoking causes a rapid decrease in NO levels [37]. In our study, though statistically insignificant $(p=0.189)$, the proportion of patients with FeNO levels > 20 ppb was markedly lower in current smokers than non-smokers or ex-smokers ( $21 \%$ vs. $45 \%$ and $38 \%$ ).

Induced sputum examination in asthmatic patients is a direct method for evaluating the airways. Eosinophil percentages have been determined between $0 \%$ to $50 \%$ in asthmatic patients depending on disease severity, presence of attacks and use of steroids $[37,38]$. The threshold for the induced sputum eosinophilia was accepted as $2-3 \%$ in previous studies [9,39]. In our study, the threshold was set at $3 \%$. At the baseline visit, 13 out of 62 sputums evaluated $(21 \%)$ had an eosinophil percent higher than $3 \%$. At the follow up visit, $30 \%(n=9)$ of the 30 patients whose sputums were of sufficient quality to be evaluated had eosinophilia. Eosinophilia rates did not show any significant change. However, it is not appropriate to comment on these results because the sputum examination was possible in only half of the patients at the follow up visit. This is one of the limitations of our study. In a study by Green et al. the patients with mild or moderate asthma were treated with standard methods depending on asthma control level and pulmonary function tests or according to eosinophil rates in induced sputum. Number of asthma attacks was observed to decrease in those who were treated depending on sputum eosinophil levels [40]. However, the findings of the studies investigating the relationship between asthma-related symptoms and eosinophilic inflammation are controversial $[8,41]$. In a study on adult asthmatic patients, no difference in sputum eosinophil counts was reported between patients in the intermittent vs. mild/moderate persistent groups [8]. Sputum eosinophil rates were shown to be similar among patients who were classified according to their symptoms (e.g. without symptoms, with symptoms less than 3 days/week and with symptoms more than 3 days/week) [42]. The reason for these controversial results could be discrepancies in the description of disease severity and treatment regimen. In accordance with previous observations, we found no statistically significant relationship between asthma control levels and induced sputum eosinophil rates in our study patients. Neither was any significant change found after adjustment of the treatment regimen.

In conclusion, our evaluation of stable asthmatic patients revealed that ACT scores had no significant association with functional and inflammatory parameters such as MBPT and induced sputum eosinophil rates, although controlled patients had less bronchial reactivity and lower FeNO levels with respect to uncontrolled patients. Furthermore, a significant improvement was observed in MBPT positivity and FeNO levels at the follow up after treatment adjustment. The reason for this insignificant association between the asthma control test and inflammation parameters could be attributed to different phenotypic characteristics and clinical states of the disease.

ACKNOWLEDGEMENTS: We thank Nycomed Pharmaceutical Company for their technical assistance in the preparation of the final text of this paper.

CONFLICT OF INTEREST STATEMENT: None of the authors has any conflict of interest to declare in relation to the subject matter of this manuscript.

\section{References}

1. Buse WW, Lemanske RF Jr. Asthma. N Engl J Med 2001;344:350-362.

2. Pizzichini E, Pizzichini MM, Hargreave FE. Induced sputum in the management of asthma. Seminars in Respiratory and Critical Care Medicine 1998;19:581-592.

3. Bateman ED, Hurd SS, Barnes PJ, Bousquet J, Drazen JM, FitzGerald M, Gibson P, Ohta K, O'Byrne P, Pedersen SE, Pizzichini E, Sullivan SD, Wenzel SE, Zar HJ. Global strategy for asthma management and prevention: GINA executive summary. Eur Respir J 2008;31:143-178.

4. Bateman ED, Boushey HA, Bousquet J, Busse WW, Clark TJ, Pauwels RA, Pedersen SE; GOAL Investigators Group. Can guideline-defined asthma control be achieved? The Gaining Optimal Asthma ControL study. Am J Respir Crit Care Med 2004;170:836-844.

5. Nathan RA, Sorkness CA, Kosinski M, Schatz M, Li JT, Marcus P, Murray JJ, Pendergraft TB. Development of the asthma control test: a survey for assessing asthma control. J Allergy Clin Immunol 2004;113:59-65.

6. Juniper EF, Buist AS, Cox FM, Ferrie PJ, King DR. Validation of a standardized version of the Asthma Quality of Life
Questionnaire. Chest 1999;115:1265-1270.

7. Vollmer WM, Markson LE, O'Connor E, Sanocki LL, Fitterman L, Berger M, Buist AS. Association of asthma control with health care utilization and quality of life. Am J Respir Crit Care Med 1999;160:1647-1652.

8. Louis R, Lau LC, Bron AO, Roldaan AC, Radermecker M, Djukanović $R$. The relationship between airways inflammation and asthma severity. Am J Respir Crit Care Med 2000;161:9-16.

9. Malerba M, Ragnoli B, Radaeli A, Tantucci C. Usefulness of exhaled nitric oxide and sputum eosinophils in the longterm control of eosinophilic asthma. Chest 2008;134:733739.

10. Hamid Q, Springall DR, Riveros-Moreno V, Chanez $P$, Howarth P, Redington A, Bousquet J, Godard P, Holgate S, Polak JM. Induction of nitric oxide synthase in asthma. Lancet 1993;342:1510-1513.

11. Taylor DR, Pijnenburg MW, Smith AD, De Jongste JC. Exhaled nitric oxide measurements: clinical application and interpretation. Thorax 2006;61:817-827.

12. Berry MA, Shaw DE, Green RH, Brightling CE, Wardlaw AJ, 
Pavord ID. The use of exhaled nitric oxide concentration to identify eosinophilic airway inflammation: an observational study in adults with asthma. Clin Exp Allergy 2005;35:1175-1179.

13. Reddel HK, Taylor DR, Bateman ED, Boulet LP, Boushey HA, Busse WW, Casale TB, Chanez P, Enright PL, Gibson PG, de Jongste JC, Kerstjens HA, Lazarus SC, Levy ML, O'Byrne PM, Partridge MR, Pavord ID, Sears MR, Sterk PJ, Stoloff SW, Sullivan SD, Szefler SJ, Thomas MD, Wenzel SE; American Thoracic Society/European Respiratory Society Task Force on Asthma Control and Exacerbations. American Thoracic Society/European Respiratory Society Task Force on Asthma Control and Exacerbations. An official American Thoracic Society/European Respiratory Society statement: asthma control and exacerbations: standardizing endpoints for clinical asthma trials and clinical practice. Am J Respir Crit Care Med 2009;180:59-99.

14. Kharitonov SA, Gonio F, Kelly C, Meah S, Barnes PJ. Reproducibility of exhaled nitric oxide measurements in healthy and asthmatic adults and children. Eur Respir J 2003;21:433-438.

15. Buchvald F, Baraldi E, Carraro S, Gaston B, De Jongste J, Pijnenburg MW, Silkoff PE, Bisgaard H. Measurements of exhaled nitric oxide in healthy subjects age 4 to 17 years. J Allergy Clin Immunol 2005;115:1130-1136.

16. O'Connor GT, Sparrow D, Weiss ST. A prospective longitudinal study of methacholine airway responsiveness as a predictor of pulmonary-function decline: the Normative Aging Study. Am J Respir Crit Care Med 1995;152:87-92.

17. Szefler SJ, Phillips BR, Martinez FD, Chinchilli VM, Lemanske RF, Strunk RC, Zeiger RS, Larsen G, Spahn JD, Bacharier LB, Bloomberg GR, Guilbert TW, Heldt G, Morgan WJ, Moss MH, Sorkness CA, Taussig LM. Characterization of within-subject responses to fluticasone and montelukast in childhood asthma. J Allergy Clin Immunol 2005;115:233-242.

18. Sont JK, Willems LN, Bel EH, van Krieken JH, Vandenbroucke JP, Sterk PJ. Clinical control and histopathologic outcome of asthma when using airway hyperresponsiveness as an additional guide to long-term treatment. The AMPUL Study Group. Am J Respir Crit Care Med 1999;159:1043-1051.

19. Pavord ID, Sterk PJ, Hargreave FE, Kips JC, Inman MD, Louis R, Pizzichini MM, Bel EH, Pin I, Grootendorst DC, Parameswaran K, Djukanović R. Clinical applications of assessment of airway inflammation using induced sputum. Eur Respir J 2002;37:40s-43s.

20. American Thoracic Society Statement. Lung function testing: selection of reference values and interpretative strategies. American Thoracic Society. Am Rev Respir Dis 1991;144:1202-1218.

21. Crapo RO, Casaburi R, Coates AL, Enright PL, Hankinson JL, Irvin CG, Maclntyre NR, McKay RT, Wanger JS, Anderson SD, Cockcroft DW, Fish JE, Sterk PJ. Guidelines for metacholine and exercise challenge testing-1999. This official statement of the American Thoracic Society was adopted by the ATS Board of Directors, July 1999. Am J Respir Crit Care Med 2000;161:309-329.

22. American Thoracic Society; European Respiratory Society. ATS/ERS recommendations for standardized procedures for the online and offline measurement of exhaled lower nitric oxide and nasal nitric oxide, 2005. Am J Respir Crit Med 2005;171:912-930.

23. Popov TA, Pizzichini MM, Pizzichini E, Kolendowicz R, Punthakee Z, Dolovich J, Hargreave FE. Some technical factors influencing the induction of sputum for cell analysis. Eur Respir J 1995;8:559-565.

24. Popov T, Gottschalk R, Kolendowicz R, Dolovich J, Powers $\mathrm{P}$, Hargreave FE. The evaluation of a cell dispersion method of sputum examination. Clin Exp Allergy 1994;24:778-783. 25. Partridge MR, van der Molen T, Myrseth SE, Busse WW. Attitudes and actions of asthma patients on regular maintenance therapy: the INSPIRE study. BMC Pulm Med 2006;13:6:13.

26. Rabe KF, Wermeire PA, Soriano JB, Maier WC. Clinical management of asthma in 1999: the Asthma Insights and Reality in Europe (AIRE) study. Eur Respir J 2000;16:802807.

27. Sekerel BE, Gemicioglu B, Soriano JB. Asthma insights and reality in Turkey (AIRET) study. Respir Med 2006;100:18501854.

28. Teeter JG, Bleecker ER. Relationship between airway obstruction and respiratory symptoms in adult asthmatics. Chest 1998;113:272-277.

29. Shirai T, Furuhashi K, Suda T, Chida K. Relationship of the asthma control test with pulmonary function and exhaled nitric oxide. Ann Allergy Asthma Immunol 2008;101:608613.

30. Hanxiang N, Jiong Y, Yanwei C, Dunshuang W, Xuhong D, Xiaojun W, Changsheng L. Persistent airway inflammation and bronchial hyperresponsiveness in patients with totally controlled asthma. Int J Clin Pract 2008;62:599-605.

31. Quaedvlieg V, Sele J, Henket M, Louis R. Association between asthma control and bronchial hyperresponsiveness and airways inflammation: a cross-sectional study in daily practice. Clin Exp Allergy 2009:39;1822-1829.

32. Sazlıdere H, Çelikel S, İnönü H, Doruk S, Yılmaz A, Özyurt $\mathrm{H}$, Erkorkmaz Ü. The relation between nitric oxide levels in exhaled breath condensate and asthma control questionnaires in asthma patients. Tuberk Toraks 2010;58:5-15.

33. Agusti AG, Villaverde JM, Togores B, Bosch M. Serial measurements of exhaled nitric oxide during exacerbations of chronic obstructive pulmonary disease. Eur Respir J 1999;14:523-528.

34. Tsujino I, Nishimura M, Kamachi A, Makita H, Munakata M, Miyamoto K, Kawakami Y. Exhaled nitric oxide-is it really a good marker of airway inflammation in bronchial asthma? Respiration 2000;67:645-651.

35. Sippel JM, Holden WE, Tilles SA, O'Hollaren M, Cook J, Thukkani N, Priest J, Nelson B, Osborne ML. Exhaled nitric oxide levels correlate with measures of disease control in asthma. J Allergy Clin Immunol 2000;106:645-650.

36. Ricciardolo FL, Sterk PJ, Gaston B, Folkerts G. Nitric oxide in health and disease of the respiratory system. Physiol Rev 2004;84:731-765.

37. Horváth I, Donnelly LE, Kiss A, Balint B, Kharitonov SA, Barnes PJ. Exhaled nitric oxide and hydrogen peroxide concentrations in asthmatic smokers. Respiration 2004;71:463468.

38. Brightling CE. Clinical applications of induced sputum. Chest 2006;129:1344-1348.

39. Duong M, Subbarao P, Adelroth E, Obminski G, Strinich $T$, Inman M, Pedersen S, O'Byrne PM. Sputum eosinophils and the response of corticosteroid in asthma exerciseinduced bronchoconstriction to corticosteroid in asthma. Chest 2008;133:404-411.

40. Balbi B, Pignatti $P$, Corradi $M$, Baiardi $P$, Bianchi L, Brunetti G, Radaeli A, Moscato G, Mutti A, Spanevello A, Malerba M. Bronchoalveolar lavage, sputum and exhaled clinically relevant inflammatory markers: values in healthy adults. Eur Respir J 2007;30:769-781.

41. Green RH, Brightling CE, McKenna S, Hargadon B, Parker D, Bradding P, Wardlaw AJ, Pavord ID. Asthma exacerbations and sputum eosinophil counts: a randomised controlled trial. Lancet 2002;360:1715-1721.

42. Wilson NM, Bridge P, Spanevello A, Silverman M. Induced sputum in children: feasibility, repeatability, and relation of findings to asthma severity. Thorax 2000;55:768-774. 